\title{
Aeroplysinin-1, a Sponge-Derived Multi-Targeted Bioactive Marine Drug
}

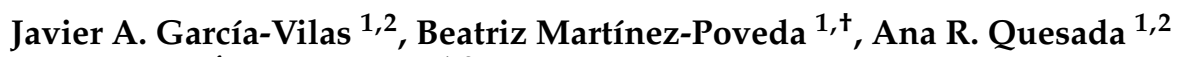 \\ and Miguel Ángel Medina ${ }^{1,2, *}$
}

Received: 13 October 2015; Accepted: 16 December 2015; Published: 22 December 2015

Academic Editor: Keith B. Glaser

1 Departamento de Biología Molecular y Bioquímica, Facultad de Ciencias, and IBIMA (Biomedical Research Institute of Málaga), Universidad de Málaga, Andalucía Tech, Málaga 29071, Spain; jandrovil@hotmail.com (J.A.G.-V.); bmpoveda@gmail.com (B.M.-P.); quesada@uma.es (A.R.Q.)

2 CIBER de Enfermedades Raras (CIBERER), Málaga E-29071, Spain

* Correspondence: medina@uma.es; Tel.: +34-9521-37132; Fax: +34-9521-32000

† Present address: Departamento de Desarrollo y Reparación Cardiovascular, Centro Nacional de Investigaciones Cardiovasculares (CNIC), Madrid 28029, Spain.

\begin{abstract}
Organisms lacking external defense mechanisms have developed chemical defense strategies, particularly through the production of secondary metabolites with antibiotic or repellent effects. Secondary metabolites from marine organisms have proven to be an exceptionally rich source of small molecules with pharmacological activities potentially beneficial to human health. $(+)$-Aeroplysinin-1 is a secondary metabolite isolated from marine sponges with a wide spectrum of bio-activities. (+)-Aeroplysinin-1 has potent antibiotic effects on Gram-positive bacteria and several dinoflagellate microalgae causing toxic blooms. In preclinical studies, (+)-aeroplysinin-1 has been shown to have promising anti-inflammatory, anti-angiogenic and anti-tumor effects. Due to its versatility, (+)-aeroplysinin-1 might have a pharmaceutical interest for the treatment of different pathologies.
\end{abstract}

Keywords: (+)-aeroplysinin-1; sponges; marine drugs; inflammation; angiogenesis; cancer

\section{Introduction: Chemical Defense of Sponges}

Sponges (Phylum Poriphera), the most primitive animals, exhibit unusual features. All sponges are aquatic: over 5000 sponge species live in salty water, whereas only around 150 sponge species live in fresh water. The body of all sponges is formed of a weak aggregation of cells with mesenchymal origin inside a gelatinous matrix connected to a scaffold with calcium- or silicate carbonate and small collagen spicules. The adult animal has a sessile and filter-feeding lifestyle, and its body is very fragile since it lacks structural defenses. For this reason, a myriad of secondary metabolites is used by sponges as chemical defense mechanisms to avoid predators, other colonial organisms, and bacterial infections [1-4]. Among the secondary metabolites produced by marine sponges, a great diversity of steroids, isoprenoids, non-isoprenoids, quinones, nitrogen and nitrogen-sulfur heterocyclic compounds, alkaloids, peptides, and terpenes are included. It is worth mentioning that some of these compounds isolated from marine sponges are only synthesized in symbiotic relationships with fungi, microalgae, archea, cyanobacteria, and bacteria [5,6]. In many cases, precursors are initially synthesized and the final bio-active products are only originated after enzymatic conversion. Enzymes and lower molecular weight precursors are located in separate compartments of the sponge cells, but when the sponges are damaged, both enzymes and substrates interact, thereby yielding the bio-active secondary metabolites [7]. 
Although pharmaceutical industry research of natural products has declined over the past 20 years [8], traditionally the majority of new drugs translated into the clinic are natural products or compounds derived from them [9]. In particular, the pharmaceutical industry is investing in the search for novel drug candidates from marine-derived organisms showing anti-angiogenic and/or anti-tumor activities. Furthermore, other studies have been focused on identifying the biosynthetic pathways and enzymes involved in the generation of new semisynthetic or synthetic molecules [10]. Most of the drug candidates of marine origin have been isolated from marine invertebrates, marine sponges being the organisms most widely investigated. In fact, approximately 16,000 marine natural compounds have been isolated thus far from marine organisms [11], and more than 5300 of these compounds were isolated from marine sponges [12]. Some of the secondary metabolites exhibit activities that block key processes in mammalian cells, thereby avoiding disease progression. Thus, many of the bioactive compounds isolated from marine sponges have become a starting point for developing new compounds with biological activities with potential usefulness in treating different pathologies.

We devote the present work to reviewing the current state of knowledge regarding aeroplysinin-1, a multi-targeted brominated bioactive compound initially isolated from sponges belonging to the order Verongida.

\section{Order Verongida}

The order Verongida belongs to the largest class of sponges, Demosponges [13]. This order is represented by sponges that lack mineral spicules, and in which widely spaced sponging fibers forming dendritic or reticulate structures and fibers may be aggregated into bundles. Species of this order are distributed in tropical to temperate Atlantic, Mediterranean, and Pacific waters [14]. Order Verongida consists of four families (Aplysinidae, Ianthellidae, Aplysinellidae, and Pseudoceratinidae) that can be identified by taking into account the different structures and composition of their sponging fiber skeletons [15]. A common feature for members of the order Verongida is their ability to produce bromotyrosine derivates as secondary metabolites. Among these bromotyrosine metabolites, dibromoverongilquinol and aeroplysinin- 1 are used by Verongida sponges as chemical weapons for their defense against other organisms [16]. These compounds are synthetized into spherolous cells, but only in response to specific symbiotic relationships with other aquatic organisms, as mentioned above [17]. In fact, several studies have reported little success in the production of secondary metabolites in sponge aquaculture because the requested symbiotic microorganisms do not grow well under the aquaculture conditions $[5,18,19]$.

Microorganisms (mainly bacteria) that live associated with sponges may represent up to $40 \%$ of the total biomass of some sponges [20]. For instance, the estimated bacterial concentration in Aplysina aerophoba tissues amounts to $6.4 \pm 4.6 \times 10^{8}$ bacteria/g of sponge tissue [20]. This microbial population is highly stable in Aplysina aerophoba, prevailing $\alpha$ - and $\gamma$-Proteobacteria, Bacteroidetes, Actinobacteria, Choroflexi, and Cyanobacteria [18]. The ratio of these bacteria and their localization in the choanocyte chamber (the place where spherolous cells are located) [19] are essential for the synthesis of the characteristic brominated alkaloids of Aplysina aerophoba [21].

\section{Chemical Structure and Properties of Aeroplysinin-1}

Sponges belonging to the Aplysina genus can accumulate brominated isoxazoline alkaloids [22], such as aerophobins, isofistularin-3, aerothionin or bisoxazolidinone derivate that sometimes exceed $10 \%$ of their dry weight [7]. Long-term, quantitative seasonal variations in their production have been reported, with their maximum accumulation in summer [23]. The key biosynthetic step of these brominated alkaloids seems to be their bromination catalyzed by a flavin-dependent halogenase [13]. These compounds become substrates for their enzymatic bioconversion into aeroplysinin- 1 when sponge tissues are damaged by predators $[24,25]$. This biotransformation was initially discovered by Teeyapant and Proksch [26]. Aeroplysinin-1 can be later converted into the dienone amide 
verngiaquinol by a nitrile hydratase that has been isolated, partially purified and characterized from Aplysinia cavernicola [27].

Aeroplysinin-1 is a chiral, optically active molecule (see Figure 1). Regarding many other drugs, only one of their enantiomers is responsible for their bioactivities. The levorotatory enantiomer ((-)-aeroplysinin-1) was isolated from Ianthella ardis by Fulmor and co-workers [28]. (+)-Aeroplysinin-1 was the first brominated derivate from Aplysina aerophoba isolated by Fattorusso [29]. In 1975, the chemical synthesis of aeroplysinin-1 was achieved [30]. Although both optical isomers exhibited very similar antibacterial activity in vitro, only the dextrorotatory enantiomer has been further investigated. Through theoretic Raman optical activity (ROA) spectra, an alternative method for the configurational assignment has been proposed. Furthermore, through a combination of theoretical and experimental chiroptical studies, the most stable solution conformations have been determined [31]. This study elucidated that the most stable conformer of $(+)$-aeroplysinin- 1 is the $1 S, 6 R$ stereoisomer. Its complete IUPAC systemic name is 2-((1S,6R)-3,5-dibromo-1,6-dihydroxy-4-methoxycyclohexa-2,4-dien-1-yl)-acetonitrile. (+)-Aeroplysinin-1 has a rigid skeleton due to the cis-diene and four flexible groups capable of interacting with its biological targets [31].

\section{Aplysina aerophoba}
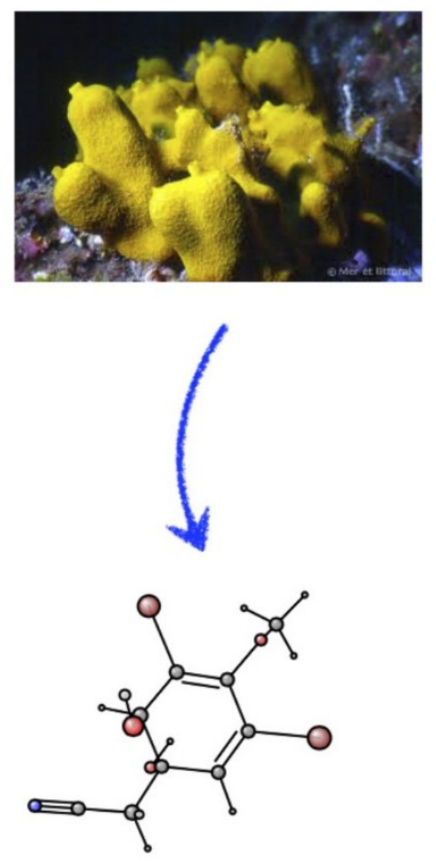

(+)-aeroplysinin-1

\section{lanthella ardis}
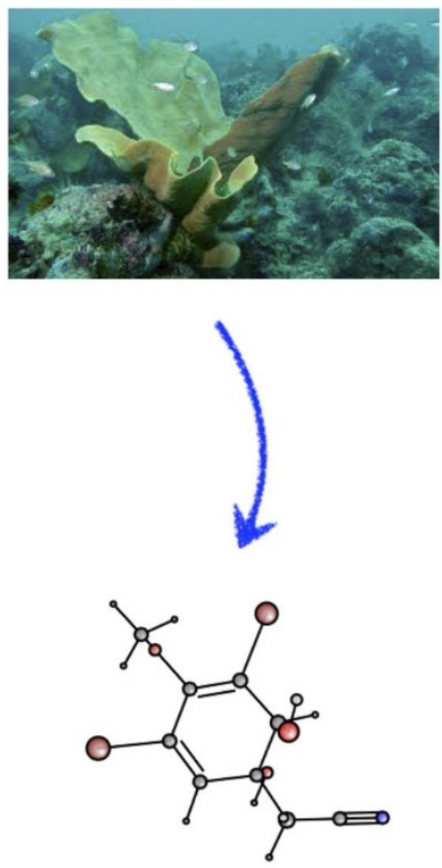

(-)-aeroplysinin-1

Figure 1. Natural sources and chemical structures of (+)- and (-)-aeroplysinin-1.

\section{Reported Antibiotic, Antimicrobial and Antiviral Properties of Aeroplysinin-1 as a Defense Metabolite}

Aeroplysinin-1 shows antibiotic, algicidal and gastropod-repellent activities, in all cases in the micromolar range. The agar diffusion assay shows that aeroplysinin-1 has relevant growth inhibition potency against Bacillus cereus, Bacillus subtilis, Staphylococcus aureus, Staphylococcus albus, Vibrio anguillarum, Flexibacter sp. and Moraxella sp. In contrast, (+)-aeroplysinin-1 did not show any effect on Gram-negative bacteria, such as Pseudomonas aeruginosa, or yeasts, including Saccharomyces cerevisiae $[29,32,33]$. Since some of the bacteria whose growth is inhibited by $(+)$-aeroplysinin- 1 are pathogenic for humans, this compound has an antibiotic potential for treating human infections that 
deserves to be further evaluated. Furthermore, (+)-aeroplysinin- 1 is able to inhibit (in a dose-response manner) the growth of the marine microalgae Coscinodiscus wailesii and Prorocentrum minimum. This is a very interesting effect, since both microalgae species are dinoflagellates causing harmful blooms. (+)-Aeroplysinin-1 has also been shown to exert a repellent activity in a time-dependent increase and dose-response manner against marine snails (Littorina littorea) [32].

(+)-Aeroplysinin-1 also exhibits an antiviral activity toward HIV-1 caused by inhibition of its reverse transcriptase activity. In fact, (+)-aeroplysinin-1 blocks the RNA-dependent DNA polymerase activity and the RNase $\mathrm{H}$ activity in a dose-dependent manner, with a high percentage of inhibition $(74 \%)$ at $20 \mu \mathrm{M}$. Moreover, $10 \mu \mathrm{M}(+)$-aeroplysinin-1 inhibits the nuclear import of both the virus reverse transcriptase and retroviral DNA by $67 \%$ [34]. These data indicate that (+)-aeroplysinin- 1 is able to inhibit key stages of the HIV-1 infection.

Table 1 shows the $\mathrm{IC}_{50}$ values reported for several microorganisms treated with $(+)$-aeroplysinin-1. Figure 2 summarizes the antibiotic properties reported for (+)-aeroplysinin-1.

Table 1. $\mathrm{IC}_{50}$ values of the antibiotic action demonstrated for (+)-aeroplysinin- 1 on bacteria, microalgae and viruses.

\begin{tabular}{ccc}
\hline Microorganism Species & IC $_{\mathbf{5 0}}(\boldsymbol{\mu M})$ & Reference \\
\hline P. phosphoreum & 3.5 & {$[32]$} \\
C. wailesii & 5.6 & {$[32]$} \\
P. minimum & 7.0 & {$[32]$} \\
HIV-1 & 14.6 & {$[34]$} \\
\hline $\mathrm{IC}_{50}$ is the drug concentration causing $50 \%$ survival inhibition in endothelial cell lines.
\end{tabular}<smiles>COC1=C(Br)[C@@H](O)[C@](O)(CC#N)C=C1Br</smiles>

$(+)$-aeroplysinin-1

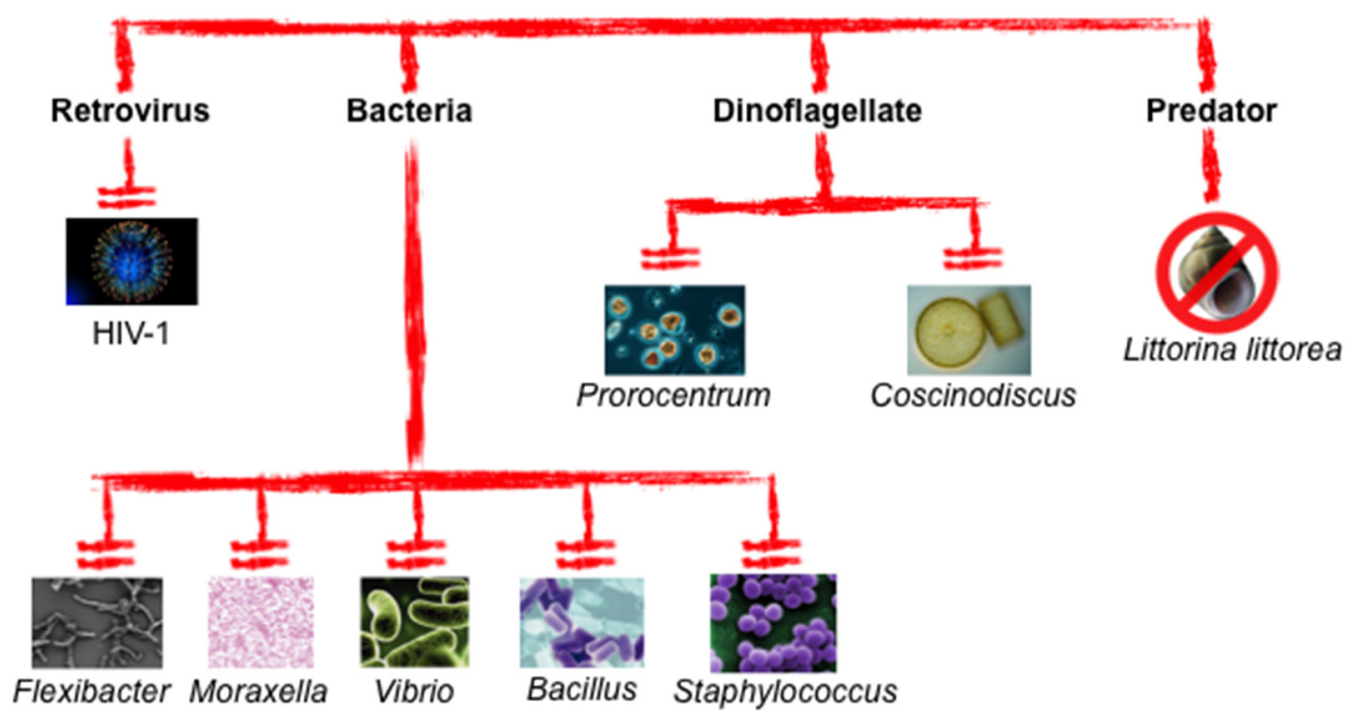

Figure 2. (+)-Aeroplysinin-1 exhibits a wide spectrum of antibiotic action. 


\section{Aeroplysinin-1 as an Anti-Inflammatory Compound}

The inflammatory response is a defense mechanism that protects against pathogenic organisms [35]. However, it is also related to allergy, pathological angiogenesis and tumor progression [36,37]. Once the inflammatory response is triggered, endothelial cells that are close to the inflammation focus release new inflammatory molecules and subsequently contributing to a positive feedback loop [38].

In vitro assays with human umbilical vein endothelial cells (HUVEC) and human monocytic leukemia cell line (THP-1) revealed that (+)-aeroplysinin-1 treatment was able to modulate key proteins of the inflammatory process [38]. In the case of HUVEC, treatments of HUVEC with 10-20 $\mu \mathrm{M}(+)$-aeroplysinin-1 decreased the expression levels of mRNA and the protein levels corresponding to the inflammatory mediators monocyte chemoattractant protein 1 (MCP-1), thrombospondine-1 (TSP-1), and cyclooxygenase 2 (COX-2). These treatments also decreased the protein levels of interleukin 1 alpha (Il-1 $\alpha$ ) and matrix metalloproteinase 1 (MMP-1), as summarized in Table 2. On the other hand, THP-1 cells treated with $10 \mu \mathrm{M}(+)$-aeroplysinin-1 showed decreased expression levels of MCP-1 and COX-2, as determined by real-time qPCR [38]. Taken together, these results strongly suggest that (+)-aeroplysinin- 1 could be a novel anti-inflammatory compound with potential pharmacological action on inflammation-dependent diseases.

Table 2. Molecular targets that are modulated by (+)-aeroplysinin-1 in endothelial cells.

\begin{tabular}{cccccc}
\hline Cell Line & $\begin{array}{c}\text { Treatment } \\
(\boldsymbol{\mu} \mathbf{M})\end{array}$ & Target & Effect & Activity & Reference \\
\hline EVLC-2 & 2.5 & MMP-2 & Decrease & Anti-angiogenic & {$[38]$} \\
HUVEC & 2.5 & MMP-2 & Decrease & Anti-angiogenic & {$[38]$} \\
HUVEC & 10 & MCP-1 & Decrease & Anti-inflammatory [38] \\
HUVEC & 10 & TSP-1 & Decrease & Anti-inflammatory [38] \\
HUVEC & 10 & COX-2 & Decrease & Anti-inflammatory [38] \\
HUVEC & 20 & Il-1 $\alpha$ & Decrease & Anti-inflammatory [38] \\
HUVEC & 20 & MMP-1 & Decrease & Anti-inflammatory [38] \\
RF-24 & 2.5 & MMP-2 & Decrease & Anti-angiogenic & {$[38]$} \\
BAEC & 10 & Cleaved lamin-A & Increase & Apoptogenic & {$[39]$} \\
BAEC & 10 & Caspase-2, -3, -8, -9 & Increase & Apoptogenic & {$[39]$} \\
BAEC & 10 & Cytochrome C & Increase in cytoplasm & Apoptogenic & {$[39]$} \\
HUVEC & 10 & p-Bad & Increase & Apoptogenic & {$[39]$} \\
BAEC & 3 & MMP-2 & Decrease & Anti-angiogenic & {$[40]$} \\
BAEC & 3 & PA & Decrease & Anti-angiogenic & {$[40]$} \\
BAEC & 3 & PAI & Increase & Anti-angiogenic & {$[40]$} \\
\hline
\end{tabular}

BAEC: bovine aortic endothelial cells, HUVEC: human umbilical vein endothelial cells, EVLC-2: SV40 large T-antigen immortalized human umbilical vein cells; RF-24: papillomavirus 16 E6/E7 immortalized human umbilical vein cells; HMEC: human microvascular endothelial cells.

\section{Aeroplysinin-1 as an Anti-Angiogenic Compound}

The proper functioning and modulation of the angiogenesis process is essential during embryonic development. In adults, angiogenesis is tightly restricted and deregulated. Persistent angiogenesis is related to the progression of a number of so-called angiogenesis-dependent diseases, including retinopathies, arthritis, psoriasis and cancer, among many others [41]. Endothelial cells are the main ones responsible for the formation of new capillaries in angiogenesis. (+)-Aeroplysinin-1 inhibits the growth of endothelial cells (Table 3). This effect can be due, at least in part, to the apoptogenic effects of this compound [39]. 
Table 3. $\mathrm{IC}_{50}$ values of (+)-aeroplysinin-1 on endothelial cell proliferation.

\begin{tabular}{ccc}
\hline Endothelial Cell Line & IC $_{\mathbf{5 0}}(\boldsymbol{\mu} \mathbf{M})$ & Reference \\
\hline HUVEC & 4.7 & {$[38]$} \\
EVLC-2 & 3.0 & {$[38]$} \\
RF-24 & 2.8 & {$[38]$} \\
HMEC & 2.6 & {$[38]$} \\
BAEC & 2.1 & {$[40]$} \\
\hline
\end{tabular}

BAEC: bovine aortic endothelial cells, HUVEC: human umbilical vein endothelial cells, EVLC-2: SV40 large T-antigen immortalized human umbilical vein cells; RF-24: papillomavirus 16 E6/E7 immortalized human umbilical vein cells; HMEC: human microvascular endothelial cells.

In bovine aortic endothelial cells (BAEC), (+)-aeroplysinin-1 induced apoptosis with nuclear condensation and fragmentation. Up to a six-fold increase of the sub G1 population was observed when the treated BAEC cell cycle was analyzed by flow cytometry after iodide propidium staining. This evidence was confirmed with the use of the 7-AAD/Annexin V assay [39]. This analysis demonstrated that (+)-aeroplysinin-1 induced late apoptosis. Moreover, the apoptogenic effect of the compound was elucidated, showing that it was induced through the intrinsic apoptotic pathway, as revealed by the release of cytochrome $C$ and the increase of caspase $(-2,-3,-8$, and -9) activities [39]. Along with these dramatic effects on endothelial cell proliferation and survival, (+)-aeroplysinin-1 has been shown to inhibit some other key steps of the angiogenic process, as revealed by an array of in vitro assays, such as the tube formation on Matrigel, and both the migration and chemoinvasion assays in a modified Boyden chamber. Both endothelial migration and invasion are mediated by extracellular matrix remodeling proteases, such as MMP-2 and urokinase-type plasminogen activator (uPA). Interestingly, (+)-aeroplysinin- 1 treatment of endothelial cells decreased their levels of MMP-2 and uPA, whereas it increased plasminogen activator inhibitor (PAI) levels [40]. The in vitro anti-angiogenic effects of (+)-aeroplysinin-1 was also demonstrated in human immortalized endothelial cells, both macrovascular (EVL-2 and RF-24) and microvascular (HMEC) [38]. (+)-Aeroplysinin-1 inhibited the formation of "tubule-like" structures by any of these cells lines grown on Matrigel. For the microvascular endothelial cells, the concentration of (+)-aeroplysinin-1 required to completely inhibit the tubule-like structure formation on Matrigel was lower than those required in the case of macrovascular cells. These three types of immortalized endothelial cells also decreased their MMP-2 levels when treated with (+)-aeroplysinin-1 (Table 2).

The results obtained with the in vivo chick chorioallantoic membrane (CAM) assay showed that CAM treatment with (+)-aeroplysinin-1 produced a devastating effect on the developing vessels and severe disorganization of the pre-existing vessels. These effects were probably due to the induction of apoptosis in vascular cells and their progenitors, as demonstrated by the TUNEL assay in the quail CAM [40]. Moreover, (+)-aeroplysinin-1 provoked the inhibition of the bFGF-mediated cell invasion in the in vivo Matrigel plug assay.

All these results demonstrate that (+)-aeroplysinin-1 is a potent inhibitor of both in vitro and in vivo angiogenesis. An independent research group has described the synthesis of several derivatives of $(+)$-aeroplysinin-1. Two of them, namely the epoxy ketone and the azolactone derivatives, were shown to have much stronger anti-angiogenic effects than (+)-aeroplysinin- 1 in the tubule formation on Matrigel assay [42].

\section{Aeroplysinin-1 as an Anti-Tumor Compound}

In the last decades, one of the challenges of cancer research has been the discovery of new molecular targets involved in neoplastic diseases, and new active drugs to treat them. Several reports have evaluated the (+)-aeroplysinin-1 activity in different tumor cell lines and its effects on specific molecular targets of tumors. (+)-Aeroplysinin-1 shows cytostatic [43] and cytotoxic effects (Table 4) on different types of tumor cells lines. 
Table 4. $\mathrm{IC}_{50}$ values of the anti-proliferative effect demonstrated for (+)-aeroplysinin-1 on different tumor cells.

\begin{tabular}{ccc}
\hline Tumor cell line & IC $_{\mathbf{5 0}}(\boldsymbol{\mu M})$ & Reference \\
\hline HT-1080 & 2.3 & 40 \\
HTC-116 & 4.7 & 40 \\
HeLa & 3.0 & 43 \\
THP-1 & 10.0 & 45 \\
NOMO-1 & 17.0 & 45 \\
HL-60 & 5.0 & 45 \\
\hline
\end{tabular}

HeLa: human cervix carcinoma, THP-1: human acute monocyte cell line, NOMO-1: human acute myeloid leukemia, HL-60: human promyelocytic leukemia cells, HTC-116: colorectal carcinoma cell line, HT-1080: human fibrosarcoma cell line.

For two human estrogen-responsive breast cancer cell lines (namely, MCF-7 and ZR-75-1 cells), it has been shown that (+)-aeroplysinin-1 blocks their EGF-dependent proliferation, claiming that this observed effect was caused by an inhibitory effect of (+)-aeroplysinin-1 on EGFR phosphorylation [44].

Very recently, a potent cytotoxic effect of (+)-aeroplysinin-1 on both acute myeloid cells (NOMO-1) and acute monocytic cells (THP-1) has been reported [45]. In this work, (+)-aeroplysinin-1 treatment was shown to be able to stimulate the phosphorylation of histone $\mathrm{H} 2 \mathrm{AX}(\gamma-\mathrm{H} 2 \mathrm{AX})$, which is a marker of the DNA damage. Furthermore, the same treatment also decreased the histone 3 level of phosphorylation, whereas it increased the cleavage of caspase 3, PARP, p16, and p21. These proteins are involved in mitosis, death cellular pathway, and cyclin-dependent kinase inhibition. These results could explain the increase of the sub-G1 phase population and the decrease of $\mathrm{S}$ phase population observed in an analysis of cell cycle.

\section{Is (+)-Aeroplysinin-1 a Receptor Tyrosine Kinase Inhibitor?}

Many external ligands induce specific cellular responses through their binding to membrane cell receptors. The dysregulation of receptor tyrosine kinases is a common feature for several types of cancer and for this reason receptor tyrosine kinases have become molecular targets for cancer treatment [46]. One of these molecular targets for cancer treatment is EGFR, the specific receptor for epidermal growth factor. As mentioned above, it has been claimed that (+)-aeroplysinin- 1 inhibits EGFR phosphorylation [44]. In fact, the title of that scientific article claimed that (+)-aeroplysinin-1 would inhibit the intrinsic protein tyrosine kinase activity of the EGF-receptor kinase complex from human breast cancer cells. This claim has been mentioned and referred to since 1990 by others [38,40,47-49] and can also be found in the accompanying information provided by the (+)-aeroplysinin-1 vendor Santa Cruz Biotechnology on its web page [50]. However, this claimed inhibitory effect of (+)-aeroplysinin-1 on EGFR phosphorylation has been questioned by other groups [47,51]. Initially accepting that (+)-aeroplysinin-1 had been shown [44] to inhibit EGFR tyrosine kinase in an in vitro test system, Hinterding et al. published an article in 1998 describing the synthesis and biological evaluation of (+)-aeroplysinin-1 analogs as a new class of receptor tyrosine kinase inhibitors [47]. Data contained in that article and presented in its Table 1 indeed shows that four out of the twelve tested (+)-aeroplysinin-1 analogs inhibited EGFR tyrosine kinase activity with $\mathrm{IC}_{50}$ values within the micromolar range of concentration. However, this very same table declares (+)-aeroplysinin-1 to be "inactive," that is, unable to inhibit EGFR kinase activity within the micromolar range of concentration. Our group very recently has reported the result of an in vitro kinase inhibition screening, showing that $20 \mu \mathrm{M}(+)$-aeroplysinin-1 was unable to produce any significant inhibitory effect on 25 different protein kinases, including receptor tyrosine kinases like FGFR1-4, VEGFR1-3, TGFR1-2, and c-Met [51]. Among the intracellular protein kinases tested, neither Akt nor ERK were inhibited by (+)-aeroplysinin-1. Akt and ERK are key effectors of the signaling pathways controlling cell proliferation and survival [52]. Notwithstanding this lack of direct 
in vitro inhibitory effect of (+)-aeroplysinin- 1 on these protein kinases, we could demonstrate that in both BAEC and HUVEC endothelial cells (but not in HCT-116 and HT-1080 tumor cells and in mouse embryonic fibroblasts) $2 \mathrm{~h}$ of treatment with $20 \mu \mathrm{M}$ (+)-aeroplysinin-1 was enough to induce a strong decrease in the phosphorylation levels of Akt and ERK [51].

A docking study recently reported predicts that (+)-aeroplysinin-1 could interact with the catalytic kinase domain of EGFR and suggests that a similar kind of interaction could give account of the potential inhibitory effects on (+)-aeroplysinin- 1 on other receptor tyrosine kinases such as VEGFR2 [53]. The predictions of this computational study do not seem to be valid in the real world, taking into account the previously mentioned experimental results that have demonstrated that (+)-aeroplysinin-1 is unable to inhibit kinase activities.

\section{Conclusion: Potential and Perspectives of (+)-Aeroplysinin-1 as a Novel Multi-Targeted Drug}

$(+)$-Aeroplysinin-1 is a brominated alkaloid compound produced by Verongida sponges as a chemical weapon to protect themselves from pathogens and predators. Similar to many other marine drugs, it has a wide range of potential pharmacological uses due to its effects on very different targets. (+)-Aeroplysinin-1 has anti-inflammatory, anti-angiogenic, and anti-proliferative effects and it can compromise cell survival by inducing apoptosis (see Figure 3).

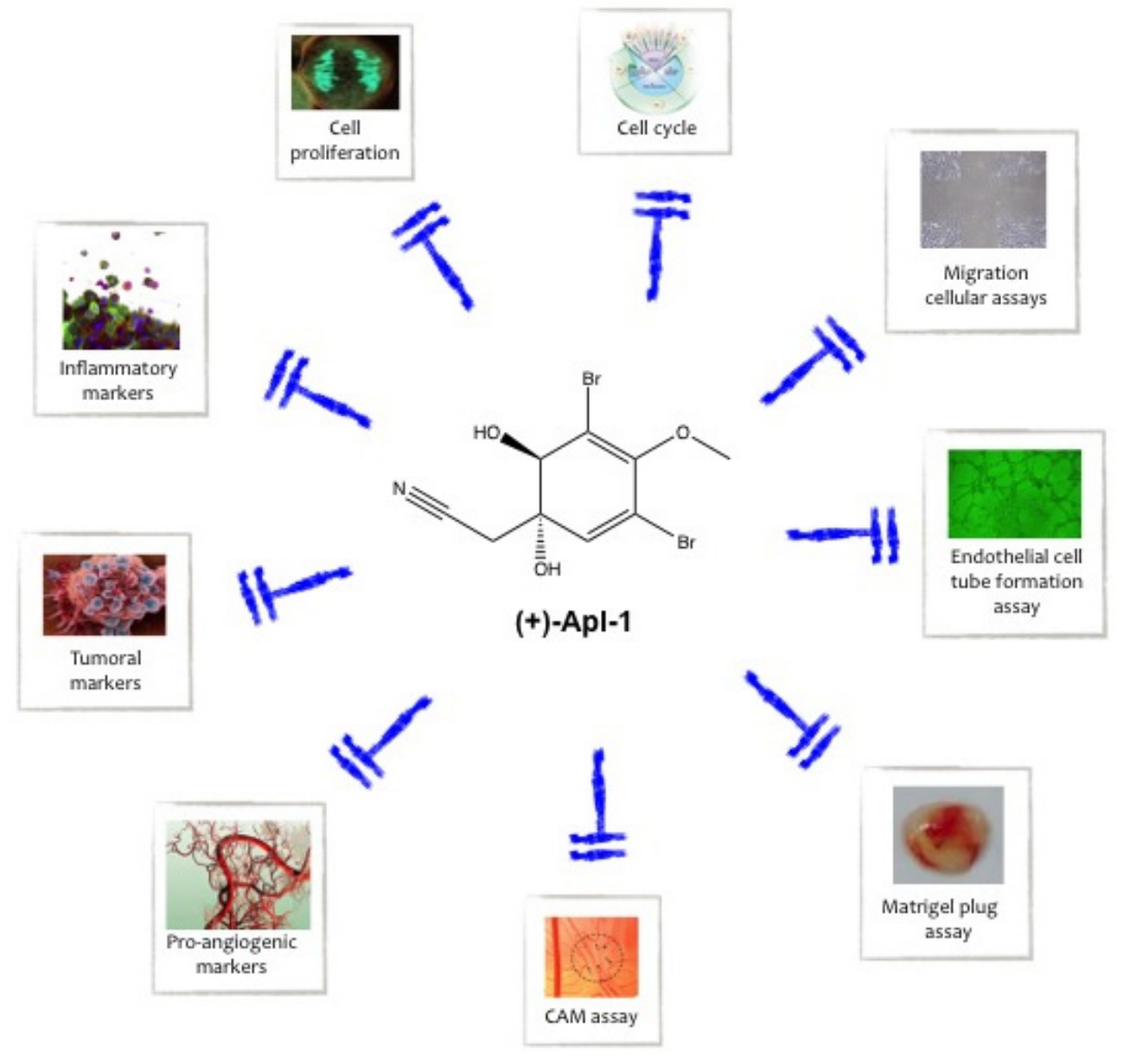

Figure 3. Summary of the biological processes inhibited by (+)-aeroplysinin-1 in animal and human cells and tissues.

Uncontrolled proliferation caused by limitless replicative potential, cell sufficiency in growth signal and/or insensitivity to growth inhibitory signals, evading apoptosis, inflammation and sustained angiogenesis are some of the so-called hallmarks of cancer, an integrative concept 
successfully introduced by Hanahan and Weinberg [37]. Since all the hallmarks of cancer are potential therapeutic targets to treat and inhibit cancer, the search for new molecules capable of inhibiting any of them is a very active research field.

In the last few years, marine species have been used as a prolific source of molecular diversity with many new bioactive compounds identified for pharmaceutical use [54,55]. Our group has actively contributed to the search and characterization of new modulators of angiogenesis (and inhibitors of some key hallmarks of cancer) of marine origin [56-59]. In particular, we have contributed to bringing to a close the debate on the claimed receptor tyrosine kinase inhibitory effect of (+)-aeroplysinin-1 and to identify the hallmarks of cancer mentioned previously as neoplasia features targeted by this compound [38-40,51]. However, the list of currently accepted hallmarks of cancer also includes genome instability and mutation accumulation, metabolic reprogramming, avoiding immune destruction and activation of tissue invasion and metastasis [37]. The interest to demonstrate whether (+)-aeroplysinin-1 could target any of these other hallmarks of cancer warrants future research in this direction.

On the other hand, inflammation and angiogenesis are not only linked to cancer. It is accepted that inflammation is associated with the etiology of many pathological conditions and that there are a number of diseases dependent on angiogenesis. Additional experimental efforts will be needed in the future to explore the potential use of (+)-aeroplysinin- 1 and derivatives for the treatment of non-neoplastic inflammatory and angiogenic diseases. Finally, as a promising, novel multi-targeted drug, $(+)$-aeroplysinin-1 should enter into translational research programs.

Acknowledgments: Our experimental work is supported by grants BIO2014-56092-R (MINECO and FEDER) and P12-CTS-1507 (Andalusian Government and FEDER). The "CIBER de Enfermedades Raras" is an initiative from the ISCIII (Spain). JAGV has the financial support of Vicerrectorado de Investigación y Transferencia (University of Málaga, Spain). The funders had no role in the study design, data collection and analysis, decision to publish or preparation of the manuscript.

Author Contributions: J.A.G.V. performed the primary literature search and wrote a preliminary draft of the manuscript. M.A.M. wrote a completely new version based on the preliminary draft and supervised the work carried out by J.A.G.V. B.M.P. contributed with data. A.R.Q. carried out a first correction of the manuscript wirtten by M.A.M. All the authors read and approved the final version of the manuscript.

Conflict of Interest: The authors declare no conflict of interest.

\section{References}

1. Paul, V.J. Activation of chemical defenses in the tropical green algae Halimeda spp. J. Exp. Mar. Biol. Ecol. 1992, 160, 191-203. [CrossRef]

2. Engel, S.; Jensen, P.R.; Fenical, W. Chemical ecology of marine microbial defense. J. Chem. Ecol. 2002, 28, 1971-1985. [CrossRef] [PubMed]

3. Walters, K.D.; Pawlik, J.R. Is there a trade-off between wound-healing and chemical defenses among Caribbean reef sponges? Integr. Comp. Biol. 2005, 45, 352-358. [CrossRef] [PubMed]

4. Green, G. Ecology of toxicity in marine sponges. Mar. Biol. 1977, 40, 207-215. [CrossRef]

5. Koopmans, M.; Martens, D.; Wijffels, R.H. Towards commercial production of sponge medicines. Mar. Drugs 2009, 7, 787-802. [CrossRef] [PubMed]

6. Unson, M.D.; Holland, N.D.; Faulkner, D.J. A brominated secondary metabolite synthesized by the cyanobacterial symbiont of a marine sponge and accumulation of the crystalline metabolite in the sponge tissue. Mar. Biol. 1994, 119, 1-11. [CrossRef]

7. Thoms, C.; Ebel, R.; Proksch, P. Activated chemical defense in Aplysina sponges revisited. J. Chem. Ecol. 2006, 32, 97-123. [CrossRef] [PubMed]

8. Li, J.W.; Vederas, J.C. Drug discovery and natural products: End of an era or an endless frontier? Science 2009, 325, 161-165. [CrossRef] [PubMed]

9. Harvey, A.L.; Clark, R.L.; Mackay, S.P.; Johnston, B.F. Current strategies for drug discovery through natural products. Exp. Opin. Drug Dis. 2010, 5, 559-568. [CrossRef] [PubMed]

10. Wohlleben, W.; Pelzer, S. New compounds by combining "Modern" genomics and "Old-Fashioned" mutasynthesis. Chem. Biol. 2002, 9, 1163-1164. [CrossRef] 
11. Datta, D.; Nath Talapatra, S.; Swarnakar, S. Bioactive compounds from marine invertebrates for potential medicines-An overview. Int. Lett. Nat. Sci. 2015, 7, 42-61. [CrossRef]

12. Laport, M.S.; Santos, O.C.S.; Muricy, G. Marine sponges: Potential sources of new antimicrobial drugs. Curr. Pharm. Biotechnol. 2009, 10, 86-105. [CrossRef] [PubMed]

13. Kunze, K.; Niemann, H.; Ueberlein, S.; Schulze, R.; Ehrlich, H.; Brunner, E.; Proksch, P.; Van Pée, K.H. Brominated skeletal components of the marine demosponges, Aplysina cavernicola and Ianthella basta: Analytical and biochemical investigations. Mar. Drugs 2013, 11, 1271-1287. [CrossRef] [PubMed]

14. Diaz, M.C.; Thacker, R.W.; Redmond, N.E.; Matterson, K.O.; Collins, A.G. Phylogenetic novelties and geographic anomalies among tropical verongida. Integr. Comp. Biol. 2013, 53, 482-494. [CrossRef] [PubMed]

15. Erwin, P.M.; Thacker, R.W. Phylogenetic analyses of marine sponges within the order Verongida: A comparison of morphological and molecular data. Invertebr. Biol. 2007, 126, 220-234. [CrossRef]

16. Ivanova, E.P.; Kuznetsova, T.A.; Mikhailov, V.V. Antifungal compounds produced by bacterial populations of the Sea Sponge Verongia sp. Russ. J. Mar. Biol. 2000, 26, 118-119. [CrossRef]

17. Muscholl-Silberhorn, A.; Thiel, V.; Imhoff, J.F. Abundance and bioactivity of cultured sponge-associated bacteria from the Mediterranean Sea. Microb. Ecol. 2008, 55, 94-106. [CrossRef] [PubMed]

18. Gerçe, B.; Schwartz, T.; Voigt, M.; Rühle, S.; Kirchen, S.; Putz, A.; Proksch, P.; Obst, U.; Syldatk, C.; Husamann, R. Morphological, bacterial, and secondary metabolite changes of Aplysina aerophoba upon long-term maintenance under artificial conditions. Microb. Ecol. 2009, 58, 865-878. [CrossRef] [PubMed]

19. Turon, X.; Becerro, M.; Uriz, M.J. Distribution of brominated compounds within the sponge Aplysina aerophoba: Coupling of X-ray microanalysis with cryofixation techniques. Cell Tissue Res. 2000, 301, 311-322. [CrossRef] [PubMed]

20. Friedrich, A. Temporal variation of the microbial community associated with the mediterranean sponge Aplysina aerophoba. FEMS Microbiol. Ecol. 2001, 38, 105-113. [CrossRef]

21. Ciminiello, P.; Fattorusso, E.; Forino, M.; Magno, S.; Pansini, M. Chemistry of verongida sponges VIII-Bromocompounds from mediterranean sponges Aplysina aerophoba and Aplysina cavernicola. Tetrahedron 1997, 53, 6565-6572. [CrossRef]

22. Kochanowska, A.J.; Rao, K.V.; Childress, S.; El-Alfy, A.; Matsumoto, R.R.; Kelly, M.; Stewart, G.S.; Sufka, K.J.; Hamann, M.T. Secondary metabolites from three Florida sponges with antidepressant activity. J. Nat. Prod. 2008, 71, 186-189. [CrossRef] [PubMed]

23. Sacristán-Soriano, O.; Banaigs, B.; Becerro, M.A. Temporal trends in the secondary metabolite production of the sponge Aplysina aerophoba. Mar. Drugs 2012, 10, 677-693. [CrossRef] [PubMed]

24. Ebel, R.; Brenzinger, M.; Kunze, A.; Gross, H.J.; Proksch, P. Wound activation of protoxins in marine sponge Aplysina aerophoba. J. Chem. Ecol. 1997, 23, 1451-1462. [CrossRef]

25. Lira, N.S.; Carneiro-Montes, R.; Fechine-Tavares, J.; Sobral da Silva, M.; da Cunha, E.; Filgueiras, P.; Rodrigues, L.C.; da Silva Dias, C.; Barbosa-Fiho, J.M. Brominated compounds from marine sponges of the genus Aplysina and a compilation of their ${ }^{13}$ C NMR spectral data. Mar. Drugs 2011, 9, 2316-2368. [CrossRef] [PubMed]

26. Teeyapant, R.; Proksch, P. Biotransformation of brominated compounds in the marine sponge Verongia aerophoba-Evidence for an induced chemical defense? Naturwissenschaften 1993, 80, 369-370. [CrossRef]

27. Lipowicz, B.; Hanekop, N.; Schmitt, L.; Proksch, P. An aeroplysinin-1 specific nitrile hydratase isolated from the marine sponge Aplysina cavernicola. Mar. Drugs 2013, 11, 3046-3067. [CrossRef] [PubMed]

28. Fulmor, W.; Van Lear, G.E.; Morton, G.O.; Mills, R.D. Isolation and absolute configuration of the aeroplysinin I enantiomorphic pais from Ianthella ardis. Tetrahedron. Lett. 1970, 52, 4551-4552. [CrossRef]

29. Fattorusso, E.; Minale, L.S.G. Aeroplysinin-1, an antibacterial bromo-compound from the sponge Verongia aerophoba. J. Chem. Soc. 1972, 1, 16-18. [CrossRef]

30. Andersen, R.J.; Faulkner, D.J. Synthesis of aeroplysinin-1 and related compounds. J. Am. Chem. Soc. 1975, 97, 936-937. [CrossRef]

31. Nieto-Ortega, B.; Casado, J.; Blanck, E.W.; López-Navarrete, J.; Quesada, A.R.; Ramírez, F.J. Raman optical activity spectra and conformational elucidation of chiral drugs. The case of the antiangiogenic aeroplysinin-1. J. Phys. Chem. A 2011, 115, 2752-2755. [CrossRef] [PubMed]

32. Weiss, B.; Ebel, R.; Elbrächter, M.; Kirchner, M.; Proksch, P. Defense metabolites from the marine sponge Verongia aerophoba. Biochem. Syst. Ecol. 1996, 24, 1-12. [CrossRef] 
33. Teeyapant, R.; Woerdenbag, H.J.; Kreis, P.; Hacker, J.; Wray, V.; Witte, L.; Proksch, P. Antibiotic and cytotoxic activity of brominated compounds from the marine sponge Verongia aerophoba. Z. Naturforsch. C 1993, 48, 939-945. [PubMed]

34. Gómez-Archila, L.; Zapata, W.; Galeano, E.; Martínez, A.; Díaz, F.J.; Rugeles, M.T. Bromotyrosine derivatives from marine sponges inhibit the HIV-1 replication in vitro. VITAE. Rev. Fac. Quimica Farm. 2014, 21, 114-125.

35. Aderem, A.; Ulevitch, R.J. Toll-like receptors in the induction of the innate immune response. Nature 2000, 406, 782-787. [CrossRef] [PubMed]

36. Fulkerson, P.C.; Rothenberg, M.E. Targeting eosinophils in allergy, inflammation and beyond. Nat. Rev. Drug Discov. 2013, 12, 117-129. [CrossRef] [PubMed]

37. Hanahan, D.; Weinberg, R.A. Hallmarks of cancer: The next generation. Cell 2011, 144, 646-674. [CrossRef] [PubMed]

38. Martínez-Poveda, B.; García-Vilas, J.A.; Cárdenas, C.; Melgarejo, E.; Quesada, A.R.; Medina, M.A. The brominated compound aeroplysinin-1 inhibits proliferation and the expression of key pro-inflammatory molecules in human endothelial and monocyte cells. PLoS ONE 2013, 8, e55203. [CrossRef] [PubMed]

39. Martínez-Poveda, B.; Rodríguez-Nieto, S.; García-Caballero, M.; Medina, M.A.; Quesada, A.R. The antiangiogenic compound aeroplysinin-1 induces apoptosis in endothelial cells by activating the mitochondrial pathway. Mar. Drugs 2012, 10, 2033-2046. [CrossRef] [PubMed]

40. Rodríguez-Nieto, S.; González-Iriarte, M.; Carmona, R.; Muñoz-Chápuli, R.; Medina, M.A.; Quesada, A.R. Antiangiogenic activity of aeroplysinin-1, a brominated compound isolated from a marine sponge. FASEB J. 2001, 16. [CrossRef]

41. Rodríguez-Caso, L.; Reyes-Palomares, A.; Sánchez-Jiménez, F.; Quesada, A.R.; Medina, M.A. What is knwon on angiogenesis-related rare diseases? A systematic review of literature. J. Cell. Mol. Med. 2012, 16, 2872-2893. [CrossRef] [PubMed]

42. Córdoba, R.; Salvaro-Tormo, N.; Fernñandez-Medarde, A.; Plumet, J. Angiogenic versus cytotoxic activity in analogues of aeroplysinin-1. Bioorg. Med. Chem. 2007, 15, 5300-5315. [CrossRef] [PubMed]

43. Kreuter, M.H.; Bernd, A.; Holzmann, H.; Müller.Klieser, W.; Maidhof, A.; Weissmann, N.; Kljajic, Z.; Batel, R.; Schröder, H.C.; Müller, W.E.G. Cytostatic activity of aeroplysinin-1 against lymphoma and epithelioma cells. Z. Naturforsch. C 1989, 44, 680-688. [PubMed]

44. Kreuter, M.H.; Leake, R.E.; Rinaldi, F.; Müller-Klieser, W.; Maidhof, A.; Müller, W.E.; Schröder, H.C. Inhibition of intrinsic protein tyrosine kinase activity of EGF-receptor kinase complex from human breast cancer cells by the marine sponge metabolite (+)-aeroplysinin-1. Comp. Biochem. Physiol. B 1990, 97, 151-158. [CrossRef]

45. Stuhldreier, F.; Kassel, S.; Schumacher, L.; Wesselborg, S.; Proksch, P.; Fritz, G. Pleiotropic effects of spongean alkaloids on mechanisms of cell death, cell cycle progression and DNA damage response (DDR) of acute myeloid leukemia (AML) cells. Cancer Lett. 2015, 361, 39-48. [CrossRef] [PubMed]

46. Takeuchi, K.; Ito, F. Target Therapy for Cancer: Anti-cancer drugs targeting growth-factor signaling molecules receptor tyrosine kinases and targeted cancer therapeutics. Biopharm. Bull. 2011, 34, 1774-1780. [CrossRef]

47. Hinterding, K.; Knebel, A.; Herrlich, P.; Waldmann, H. Synthesis and biological evaluation of aeroplysinin analogues: A new class of receptor tyrosine kinase inhibitors. Bioorg. Med. Chem. 1998, 6, 1153-1162. [CrossRef]

48. Koulman, A.; Proksch, P.; Rainer, E.; Beekman, A.C.; van Uden, W.; Konings, A.W.T.; Pedersen, J.A.; Pras, N.; Woerdenbag, J. Cytotoxicity and mode of action aeroplysinin-1 and a related dienone from the sponge Aplysina aerophoba. J. Nat. Prod. 1996, 59, 591-594. [CrossRef] [PubMed]

49. Perović-Ottstadt, S.; Adell, T.; Proksch, P.; Wiens, M.; Korzhev, M.; Gamulin, V.; Müller, I.M.; Müller, W.E.G. A $(1 \rightarrow 3)-\beta$-D-glucan recognition protein from the sponge Suberites domuncula. Mediated activation of fibrinogen-like protein and epidermal growth factor gene expression. Eur. J. Biochem. 2004, 271, 1924-1937.

50. (+)-Aeroplysinin-1 (CAS 28656-91-9). Available online: http://www.scbt.com/es/datasheet-202445aeroplysinin-1.html (accessed on 11 October 2015).

51. Martínez-Poveda, B.; Quesada, A.R.; Medina, M.A. (+)-Aeroplysinin-1 inhibits Akt and ERK pathway signaling selectively in endothelial cells. Integr. Cancer Sci. Ther. 2015, 2, 181-184. 
52. Muñoz-Chápuli, R.; Quesada, A.R.; Medina, M.A. Angiogenesis and signal transduction in endothelial cells. Cell. Mol. Life Sci. 2004, 61, 2224-2243. [CrossRef] [PubMed]

53. García-Godoy, M.J.; López-Camacho, E.; García-Nieto, J.; Aldana-Montes, A.J. Solving molecular docking problems with multi-objective metaheuristics. Molecules 2015, 20, 10124-10183. [CrossRef] [PubMed]

54. Bhatnagar, I.; Kim, S.K. Immense essence of excellence: Marine microbial bioactive compounds. Mar. Drugs 2010, 8, 2673-2701. [CrossRef] [PubMed]

55. Imhoff, J.F.; Labes, A.; Wiese, J. Bio-mining the microbial treasures of the ocean: New natural products. Biotechnol. Adv. 2011, 29, 468-482. [CrossRef] [PubMed]

56. Castro, M.E.; González-Iriarte, M.; Barrero, A.F.; Salvador-Tormo, N.; Muñoz-Chápuli, R.; Medina, M.A.; Quesada, A.R. Study of puupehenone and related compounds as inhibitors of angiogenesis. Int. J. Cancer 2004, 110, 31-38. [CrossRef] [PubMed]

57. Martínez-Poveda, B.; Quesada, A.R.; Medina, M.A. The anti-angiogenic 8-epipuupehedione behaves as a potential anti-leukemic compound against HL-60 cells. J. Cell. Mol. Med. 2008, 12, 701-706. [CrossRef] [PubMed]

58. García-Caballero, M.; Marí-Beffa, M.; Cañedo, L.; Medina, M.A.; Quesada, A.R. Toluquinol, a marine fungus metabolite, is a new angiosuppresor that interferes the Akt pathway. Biochem. Pharmacol. 2013, 85, 1727-1740. [CrossRef] [PubMed]

59. García-Caballero, M.; Cañedo, L.; Fernández-Medarde, A.; Medina, M.A.; Quesada, A.R. The marine fungal metabolite, AD0157, inhibits angiogenesis by targeting the Akt signaling pathway. Mar. Drugs 2014, 12, 279-299. [CrossRef] [PubMed]

(C) 2015 by the authors; licensee MDPI, Basel, Switzerland. This article is an open access article distributed under the terms and conditions of the Creative Commons by Attribution (CC-BY) license (http:/ / creativecommons.org/licenses/by/4.0/). 